University of Nebraska - Lincoln

DigitalCommons@University of Nebraska - Lincoln

Faculty Publications: Department of Entomology

6-1982

\title{
Tolerance of the Rice Variety Triveni to the Brown Planthopper, Nilaparvata lugens
}

D. T. Ho

International Rice Research Institute

E. A. Heinrichs

International Rice Research Institute, eheinrichs2@unl.edu

F. Medrano

International Rice Research Institute

Follow this and additional works at: https://digitalcommons.unl.edu/entomologyfacpub

Part of the Agriculture Commons, and the Entomology Commons

Ho, D. T.; Heinrichs, E. A.; and Medrano, F., "Tolerance of the Rice Variety Triveni to the Brown Planthopper, Nilaparvata lugens" (1982). Faculty Publications: Department of Entomology. 909.

https://digitalcommons.unl.edu/entomologyfacpub/909

This Article is brought to you for free and open access by the Entomology, Department of at DigitalCommons@University of Nebraska - Lincoln. It has been accepted for inclusion in Faculty Publications: Department of Entomology by an authorized administrator of DigitalCommons@University of Nebraska - Lincoln. 


\title{
Tolerance of the Rice Variety Triveni to the Brown Planthopper, Nilaparvata lugens $^{1}$
}

\author{
D. T. Ho, E. A. Heinrichs, and F. Medrano
}

Department of Entomology, International Rice Research Institute, Manila, Philippines

\begin{abstract}
Seedling screening and survival and population growth studies on 30-day-old plants indicated similar degrees of susceptibility on Taichung Native 1 (TN1) and Triveni rice to Nilaparvata lugens (Homoptera: Dilphacidae). However, studies in the screenhouse and field indicated that at both the vegetative and mature stage, Triveni possesses tolerance to insect damage, expressed as the ability to survive and produce a higher percentage of productive tillers than TN1 at similar N. lugens populations. Yield reduction caused by feeding of N. lugens was ca. $40 \%$ when infested with 400 N. lugens on $35-, 50-$, or 75 -day-old plants, whereas it was almost $100 \%$ on TN1 at the same ages. Photosynthetic activity of seedling-stage Triveni was less affected than that of TN1 when severely damaged by the feeding of N. lugens.
\end{abstract}

The brown planthopper, Nilaparvata lugens (Stål), has become one of the most serious pests of rice in the last decade (Pathak and Saxena 1980). It damages the plant by sucking sap and transmitting grassy stunt, ragged stunt (Ling et al. 1978), and wilted stunt (Chen et al. 1978 ) virus diseases. A selection experiment with highly resistant varieties involving a single major resistance gene imparting antixenosis and antibiosis resulted in the selection of two biotypes which were insensitive to the resistance genes (Pathak and Heinrichs 1982). These results are similar to what occurred under natural conditions in Indonesia, the Philippines, and Vietnam, where variety IR26 (possessing the Bph1 gene for resistance) succumbed to the resistance breaking biotype 2, which replaced the wild strain, biotype 1 after ca. 3 years (Paguia et al. 1980). Because of the rapid selection for biotypes, there has been significant interest at the International Rice Research Institute (IRRI) in the possibility of 
developing rice varieties possessing tolerance, resistance which may be more stable than that of currently existing resistant varieties.

Tolerance is a basis of resistance in which the host plant has the ability to grow or reproduce normally or to compensate for the injury in spite of supporting an insect pest population that severely damages the susceptible host (Painter 1951). When a tolerant variety is grown, the natural enemies have more prey to feed on and can better sustain themselves in the field. Natural enemies then provide the major selection pressure on the pest population because they are the major mortality factor. Directional selection for a new biotype through the varieties is reduced. In terms of pest management, a high tolerance level results in a high economic threshold and less damage to the crop. Thus, the number of chemical sprays can be reduced in an integrated pest management program (Headley 1972).

The reaction of the rice variety Triveni was moderately resistant (MR) to susceptible (S) in greenhouse screening of the International Rice Brown Planthopper Nursery throughout tropical Asia, and S to resistant (R) in the field (IRRI 1979). In field screening, Triveni is able to tolerate a high population of $N$. lugens and produce grain, whereas some varieties are killed and fail to produce grain (Heinrichs, unpublished data).

This study was conducted to confirm the presence of tolerance in Triveni to N. lugens and to quantify its expression at different plant growth stages.

\section{Materials and Methods}

All tests were conducted at the IRRI at Los Baños, Laguna, Philippines. Taichung Native 1 (TN1), N. lugens susceptible, and Triveni, moderately resistant, are of similar plant stature, biomass production, and maturity. Triveni is believed to have minor genes for resistance, whereas TN1 is susceptible, having no genes for resistance (Ho 1981).

\section{Screening for Insect Damage}

\section{Greenhouse}

The seedling bulk test described by Choi (1979) was used. Test varieties were seeded in rows spaced 2 em apart in seedboxes ( 60 by 45 by $10 \mathrm{~cm}$ ). Each variety was replicated in six rows, with about 30 seedlings per row. At 6 days after seeding, second- to third-stage nymphs of $N$. lugens biotype 2 were infested evenly on the seedlings at the rate of ca. 8 insects per seedling. Grading of plant damage began at 6 days after infestation (DAI) and continued at 2-day intervals to 16 DAI. Ratings were based on the 1 to 9 visual grading scale, where 1 = highly resistant, 5 = moderately resistant, and 9 = highly susceptible (IRRI 1975).

\section{Field}

Three weeks before the planting of the test varieties, an N. lugens-susceptible line with tungro virus resistance, IR1917, was transplanted in seven-row strips, placed $2 \mathrm{~m}$ apart, running the length of a field ( 25 by $100 \mathrm{~m}$ ). These strips served as borders. At 20 days after sowing, the test entries were transplanted in 10-row plots between the strips of IR1917. The 
IR1917 strips were infested with 20 to 30 first- and second-stage nymphs per hill of biotypes 1 and $2 \mathrm{~N}$. lugens at 20,30, and 40 days after transplanting (DT). The border plots were sprayed four times with decamethrin at 2-week intervals beginning at 27 DT to promote $N$. lugens resurgence. Insects moved to the test entries when the border plots were hopperburned. Damage ratings were made three times at 60, 65, and 70 DT.

\section{Screenhouse}

To reconfirm the results of the field screening, further screening was conducted in a screenhouse $(10$ by $30 \mathrm{~m})$ in which the plants were protected from interference by predators, parasites, and vertebrate pests. Test varieties were grown in plots (1 by $1 \mathrm{~m})$ with three plots per variety. Two weeks before transplanting of the test varieties, border plants of TN1 were transplanted. The TN1 plants were infested with approximately equal proportions of biotype 1 and $2 \mathrm{~N}$. lugens at ca. 30 insects per hill at 15, 20, and 25 DT. Insect collection and damage ratings were made at 2-week intervals thereafter.

\section{Measurement of Antixenosis and Antibiosis}

\section{Test for Antixenosis}

Two tests were simultaneously conducted, one on plants aged 10 days after seeding (DS) and another on plants aged 60 DS. In the 10-DS test, seedlings (30 per row) were greenhouse grown in seedboxes in 20-cm rows spaced $2 \mathrm{~cm}$ apart. Each row served as a replicate, and six replicates were planted of each variety. Approximately equal proportions of $N$. lugens biotype 2 males and females were infested evenly between rows. Number of insects alighting on each seedling was determined by counting at 12,24 , and $72 \mathrm{~h}$ after infestation (HAI).

In the 60-DS plants individual tillers with roots intact were taken from potted plants. The tillers were placed in test tubes containing a culture solution (Yoshida et al. 1976) and randomly arranged in a square test tube rack. Cardboard, with holes just large enough for the tillers to protrude through, was placed at the top of the test tubes and served as a floor. Equal proportions of 2-day-old males and females were released evenly on the floor at the rate of ca. 25 per tiller. Number of insects alighting on the test varieties was recorded at 12 , 24, and 72 HAI. Each treatment was replicated 10 times.

\section{Survival and Population Growth}

Three 10-day-old seedlings of TN1, Triveni, and Ptb 33 (resistant check) were planted in 16-cm-diameter clay pots. Plants were caged with 10 newly hatched biotype 2 nymphs at 30 DT. The cage consisted of a cylinder $(13$ by $90 \mathrm{~cm})$ made of Mylar film containing finemesh nylon screen windows for ventilation. Insects were counted at $20 \mathrm{DAI}$ to determine percent survival and left in the cage to reproduce. At $40 \mathrm{DAI}$, all the insects in each cage were counted to determine population growth. Each cage served as a replicate, and each treatment was replicated five times. 


\section{Measurement of Tolerance}

\section{$\mathrm{CO}_{2}$ Uptake at the Seedling Stage}

To determine the extent to which photosynthetic activity of TN1 and Triveni plants is reduced when damaged by $N$. lugens feeding, 10-day-old seedlings were grown individually in culture solution (Yoshida et al. 1976) within test tubes and infested with 10 male and 10 female biotype 2 adults. The test tube opening was plugged with cotton to prevent escape of insects. Dead insects were replaced every $12 \mathrm{~h}$ to maintain a consistent density. At $3 \mathrm{DAI}$, seedlings showing severe damage symptoms with chlorotic and withered leaves and curled leaf tips were transferred to leaf chambers (Fig. 1). Individual plants were maintained with culture solution in a small glass container and infested with five brachypterous females in a small plastic cage on top of the culture solution container. Two sets of five leaf chambers each were used for five healthy and five damaged plants of each variety. Plants were illuminated with two banks of lights, each composed of nine incandescent 75-W bulbs. Lights were placed $3 \mathrm{~m}$ from the plants and left on for a $24-\mathrm{h}$ period.

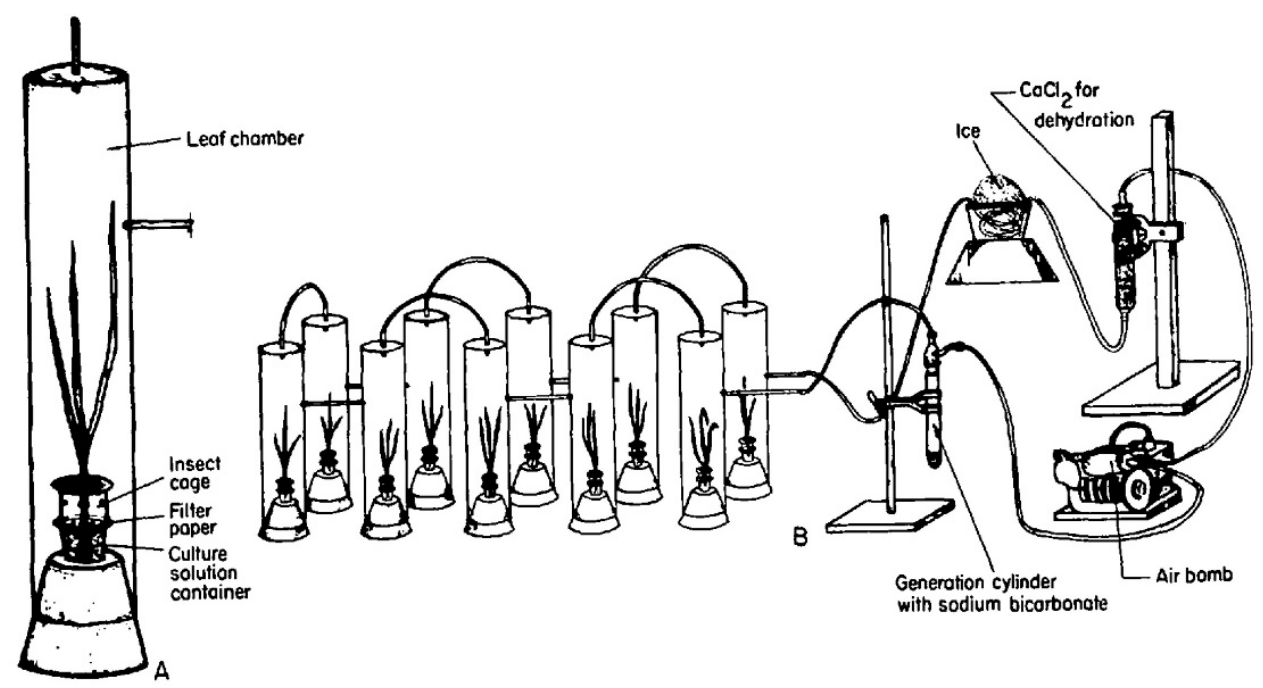

Figure 1. Schematic diagram of the apparatus used to determine the photosynthetic rate of rice seedlings using ${ }^{14} \mathrm{CO}_{2}$. (A) Enlarged leaf chamber showing insect cage and filter paper for honeydew collection; (B) Apparatus consisting of 10 leaf chambers, generation cylinder, and air bomb.

Radioactive ${ }^{14} \mathrm{CO}_{2}$ was generated through the reaction between lactic acid and sodium$\mathrm{bi}^{-14}$ carbonate in a generating cylinder and circulated in a closed system by an electrical air bomb (Ruben et al. 1939). Honeydew excreted by the insects was collected on the filter paper placed on the bottom of the insect cage. After $24 \mathrm{~h}$, the plants were removed from the leaf chambers and autoradiographed on X-ray film to measure the intensity of ${ }^{14} \mathrm{C}$ incorporated. Plants, insects, and filter papers with honeydew were collected separately. Plant samples were treated with $\mathrm{H}_{2} \mathrm{O}_{2}$ for $24 \mathrm{~h}$, after which insect, plant, and honeydew samples were separately liquefied with NCS (Amersham), a solubilizer solution containing toluene 
and a strong base, for $48 \mathrm{~h}$ at $75^{\circ} \mathrm{C}$ in an incubator. The samples were then ovendried at $100^{\circ} \mathrm{C}$ for $30 \mathrm{~min}$ and diluted with $10 \mathrm{ml}$ of scintillation solution composed of the following (per liter): Toluene, $700 \mathrm{ml}$; PPO (2.5-diphenoloxazole-scintillation grade), 4 g; POPOP [1-4 bis-2 (5-phenyloxazolyl)-benzene)-scintillation grade], $100 \mathrm{~g}$; Cab-o-sil (silicon dioxide), $15 \mathrm{~g}$; and Triton X-100 (octyl phenoxy polyethoxy ethanol), $250 \mathrm{ml}$.

Radioactivity of ${ }^{14} \mathrm{C}$ was read with the Tri-carb liquid scintillation spectrometer (Series $314 \mathrm{E})$ at $1,300 \mathrm{~V}$.

Yield Reduction at Different Insect Densities

Different insect infestation levels were tested to determine the critical population causing yield reduction. At 35 DT, plants were randomly chosen in a field screening plot and caged in a nylon net cage at one hill per cage. Ten caged hills were used for each treatment. Firstto second-stage nymphs of equal proportion of biotypes 1 and 2 at different densities0 (control), 100, 200, and 400 nymphs per hill-were introduced into the nylon net cages. Insects were maintained on test varieties until harvest. Damage ratings recorded at 1 week before harvest. The insect density causing critical yield reduction on the susceptible variety TN1 and giving a significant difference between TN1 and Triveni was chosen for further study on the tolerance reaction at different plant growth stages.

Yield Reduction at Different Plant Growth Stages

An initial density of 400 nymphs per hill was found as the critical population and used to test for tolerance at 35, 55, and 75 DT. For each variety, 20 hills were individually caged in cylindrical Mylar cages. Plants were infested with equal proportions of first- and secondstage hoppers from biotype 1 and 2 greenhouse cultures. Insects were allowed to multiply for 6 weeks, after which they were collected twice at 1-week intervals. Damage ratings were taken 1 week before harvest, and yield components were recorded at harvest.

\section{Results}

\section{Screening for Insect Damage}

Damage ratings of TN1 and Triveni were similar in the seedling bulk screening test conducted in the greenhouse (Fig. 2). In the field screening, where older plants were infested, damage ratings of TN1 were slightly higher than that of Triveni. TN1 was hopperburned at $65 \mathrm{DT}$, whereas Triveni had a rating of 7 . Difference in damage between the two varieties was more distinct in the screen house test (Table 1). At 45 DT, although they had similar insect populations, TN1 had a rating of 9 and the Triveni rating was 4. Even though Triveni reached a rating of 7.5 at $60 \mathrm{DT}$, the plants survived and produced grain. 


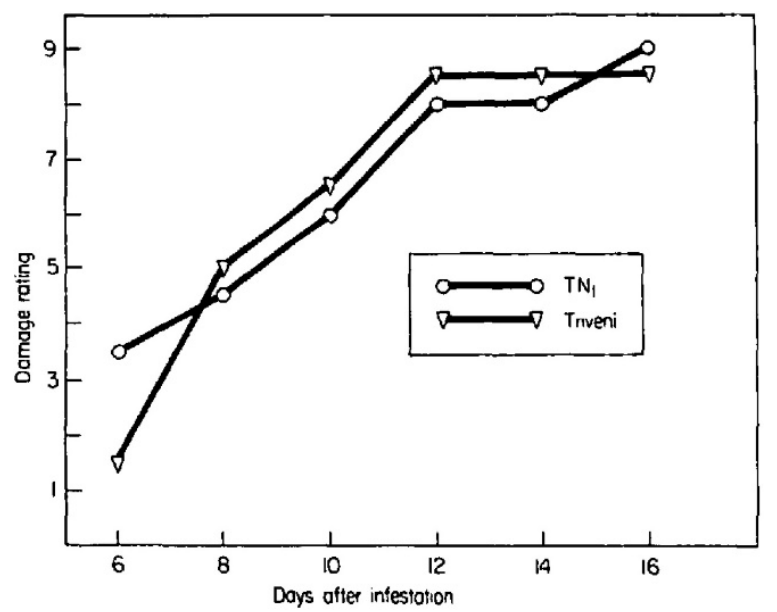

Figure 2. Damage rating of rice seedlings caused by feeding of $N$. lugens biotype 2 (scale from 1 to 9: 1 = no damage; 9 = all plants dead).

Table 1. Plant damage ratings of rice varieties TN1 and Triveni when evaluated against N. lugens under screenhouse conditions ${ }^{a}$

\begin{tabular}{lcccl}
\hline Variety & Plant age DT & N. lugens/hill & Damage rating $^{\mathrm{c}}$ & \multicolumn{1}{c}{ Plant condition } \\
\hline TN1 & 15 & $5 \mathrm{c}$ & $1.0 \mathrm{e}$ & Healthy \\
& 30 & $12 \mathrm{~b}$ & $7.5 \mathrm{~b}$ & Yellowish and stunted \\
& 45 & $92 \mathrm{a}$ & $9.0 \mathrm{a}$ & Hopperburned $^{\mathrm{d}}$ \\
& 60 & - & $9.0 \mathrm{a}$ & - \\
Triveni & 15 & $3 \mathrm{c}$ & $1.0 \mathrm{e}$ & Healthy \\
& 30 & $35 \mathrm{~b}$ & $2.4 \mathrm{~d}$ & Lower leaves yellowish \\
& 45 & $81 \mathrm{a}$ & $4.1 \mathrm{c}$ & Yellowish \\
& 60 & 11 & $7.5 \mathrm{ab}$ & Yellowish and stunted \\
\hline
\end{tabular}

${ }^{a}$ Average of 15 hills. Means of similar plant age followed by a common letter are not significantly different at the $5 \%$ level, by Duncan's multiple range test.

bDays after transplanting.

cDamage rating is based on scale from 1 to $9: 1=$ no damage, $9=$ all plants dead.

dHopperburned $=$ no recovery.

elnsect population decreased on the damaged plants. Plants were then recovered, and grain was produced.

\section{Antixenosis, Survival, and Population Growth}

Nonsignificant differences in preference for the two varieties by N. lugens was observed in either the 10- or 60-DS plants. Similar results were obtained in the screen house study (Table 1).

Studies on survival and population growth of $N$. lugens on the 30-day-old plants indicated that the two varieties were equally susceptible. Survival of $N$. lugens was 80 and $75 \%$ on TN1 and Triveni, respectively, whereas only 13\% survived on the resistant check variety, Ptb 33. The population which developed from the 10 nymphs was 890 and 751 on TN1 and Triveni, respectively, whereas it was only 2 on Ptb 33. 


\section{Measurement of Tolerance}

$\mathrm{CO}_{2}$ Uptake at the Seedling Stage

Although the seedlings suffered severely from damage caused by the hoppers, plants of Triveni exhibited a higher $\mathrm{CO}_{2}$ uptake, indicating higher photosynthetic activity than TN1 (Table 2). When healthy and damaged plants were compared, the reduction in $\mathrm{CO}_{2}$ uptake was less on Triveni than on TN1.

Table 2. ${ }^{14} \mathrm{C}$ uptake in rice seedlings and in honeydew excreted by $N$. lugens fed rice seedlings, and reduction in $\mathrm{CO}_{2}$ uptake of damaged seedlings in $24 \mathrm{~h}^{\mathrm{a}}$

\begin{tabular}{lcccc}
\hline & & \multicolumn{2}{c}{$\overline{\mathrm{x}}^{-14} \mathrm{C}$ counts/min } & \\
\cline { 3 - 4 } Variety & Treatment & Honeydew & Total ${ }^{\mathrm{b}}$ & Reduction in net $\mathrm{CO}_{2}$ uptake $(\%)^{\mathrm{c}}$ \\
\hline \multirow{2}{*}{ TN1 } & Healthy & $3.45 \mathrm{a}$ & $14.26 \mathrm{c}$ & - \\
& Damaged & $0.74 \mathrm{~b}$ & $3.77 \mathrm{~d}$ & 73.6 \\
\multirow{2}{*}{ Triveni } & Healthy & $2.73 \mathrm{a}$ & $60.33 \mathrm{a}$ & - \\
& Damaged & $0.12 \mathrm{~b}$ & $26.85 \mathrm{~b}$ & 55.5 \\
\hline
\end{tabular}

aMeans within a column followed by a common letter are not significantly different at the $5 \%$ level by Duncan's multiple range test. Mean of five replications.

${ }^{b}$ Total amount of ${ }^{14} \mathrm{C}$ taken up by rice seedlings, insect, and honeydew.

cReduction in net $\mathrm{CO}_{2}$ uptake $=[(\mathrm{CPM}$ in healthy seedling $-\mathrm{CPM}$ in damaged seedling $)(\mathrm{CPM}$ in healthy seedling) $] \times 100$

\section{Yield Reduction at Different Insect Densities}

Damage of TN1 plants was slightly higher than that of Triveni at the three insect densities (Table 3). TN1 was most sensitive to insect feeding damage, with a significant $(P<0.05)$ reduction of yield when the insect density increased from 100 to 200 and again from 200 to 400 insects per hill. This was not observed on Triveni, where there was no significant difference in yield reduction between 100 and 200 and 200 and 400 insects per hill. The highest insect density (400 insects per hill) caused considerable yield reduction of TN1 (99\%), whereas yield loss of Triveni was only $44 \%$, a difference of $55 \%$, which was highly significant $(P<0.01)$. There was also a highly significant difference in yield reduction between the two varieties at the 200 insects per hill level, but no difference at 100 insects per hill.

Table 3. Damage rating and yield reduction of rice varieties TN1 and Triveni at different levels of N. lugens infestation under field conditions ${ }^{a}$

\begin{tabular}{cccccc}
\hline \multirow{2}{*}{$\begin{array}{c}\text { N. lugens/hill } \\
\text { no. }\end{array}$} & \multicolumn{2}{c}{ Damage rating } & \multicolumn{3}{c}{ Yield reduction $(\%)^{\mathrm{c}}$} \\
\cline { 2 - 6 } & TN1 & Triveni & TN1 & Triveni & Difference \\
\hline 400 & $8.8 \mathrm{a}$ & $7.0 \mathrm{a}$ & $99 \mathrm{a}$ & $44 \mathrm{a}$ & $55^{* *}$ \\
200 & $7.2 \mathrm{a}$ & $5.4 \mathrm{~b}$ & $55 \mathrm{~b}$ & $26 \mathrm{ab}$ & $29^{* *}$ \\
100 & $7.0 \mathrm{a}$ & $6.2 \mathrm{~b}$ & $30 \mathrm{c}$ & $20 \mathrm{~b}$ & $10 \mathrm{~ns}$ \\
\hline
\end{tabular}

aMeans of 10 hills. Means within a column followed by a common letter are not significantly different at the $5 \%$ level by Duncan's multiple range test; ${ }^{* *}$, significant at $1 \%$ level; ns, not significant at $5 \%$ level. bDamage rating: $1=$ no damage; $9=$ plants dead.

cYield reduction $=$ [yield of noninfested hills - yield of infested hills) $/$ (yield of noninfested hills) $]$ 
Yield Reduction at Different Plant Growth Stages

The N. lugens population and damage ratings of TN1 and Triveni were similar when infested at 35 or 55 DT. The N. lugens population was about 500 per hill in the 35 and 55 DT treatments, which is extremely high, considering that the economic injury level is considered to be about 20 per hill (Heinrichs et al. 1979). However, there was a significant $(P<$ $0.05)$ difference in the damage ratings of TN1 and Triveni when infested at the flowering stage (75 DT). In spite of having similar damage ratings in the 35 and 55 DT treatments, yield reduction of TN1 was about double that of Triveni, with almost complete loss of yield in TN1.

Feeding of $N$. lugens had a greater effect on weight of dry-matter and yield components of TN1 than that of Triveni (Table 4). In TN1, there was an $80 \%$ reduction in dry matter below that of the check at 55 DT and a 70\% reduction at 35 and 75 DT. In Triveni, reduction of dry matter was ca. $30 \%$ at all growth stages. Tiller number in TN1 was reduced in all treatments, whereas in Triveni only the 35 and 75 DT treatments were significantly less than the checks. The percent reproductive tillers was decreased 70 to $80 \%$ in the three treatments of TN1, whereas there was no significant decrease in Triveni.

Table 4. Dry-matter production, tiller number, percent reproductive tiller, and height at harvest of rice varieties TN1 and Triveni as affected by feeding of the brown planthopper, N. lugens, at three plant growth stages ${ }^{a, b}$

\begin{tabular}{|c|c|c|c|c|c|c|c|c|}
\hline \multirow[b]{2}{*}{ Plant age (DT) } & \multicolumn{2}{|c|}{$\begin{array}{l}\text { Dry matter/hill } \\
(\mathrm{g})\end{array}$} & \multicolumn{2}{|c|}{ Tiller no. } & \multicolumn{2}{|c|}{$\begin{array}{l}\text { Reproductive tiller } \\
(\%)\end{array}$} & \multicolumn{2}{|c|}{$\begin{array}{l}\text { Height at harvest } \\
(\mathrm{cm})\end{array}$} \\
\hline & TN1 & Triveni & TN1 & Triveni & TN1 & Triveni & TN1 & Triveni \\
\hline 35 & $9.5 \mathrm{~b}$ & $12.9 \mathrm{a}$ & $14 \mathrm{~b}$ & $9 b$ & $14 b$ & $51 \mathrm{a}$ & $73.5 \mathrm{~b}$ & $75.4 \mathrm{ab}$ \\
\hline 55 & $6.0 \mathrm{~b}$ & $13.3 \mathrm{a}$ & $12 b$ & $12 \mathrm{ab}$ & $7 \mathrm{~b}$ & $48 \mathrm{a}$ & $70.4 b$ & $73.8 \mathrm{~b}$ \\
\hline 75 & $9.4 b$ & $13.2 \mathrm{a}$ & $15 b$ & $10 \mathrm{~b}$ & $15 b$ & $76 a$ & $72.9 \mathrm{~b}$ & $72.4 \mathrm{~b}$ \\
\hline Check (no insects) & $32.0 \mathrm{a}$ & $18.7 \mathrm{a}$ & $22 \mathrm{a}$ & $16 a$ & $73 a$ & $58 \mathrm{a}$ & $79.7 a$ & $77.4 a$ \\
\hline
\end{tabular}

aMeans of 10 hills in cage under field condition, infested with 400 third- and fourth-stage nymphs; insects were removed after 6 weeks.

bMeans within a column followed by a common letter are not significantly different at the $5 \%$ level by Duncan's multiple range test.

\section{Discussion}

Based on the results of the study, it is evident that tolerance is a component in the resistance of variety Triveni to N. lugens. Based on the seedling bulk screening test and the study on survival and population growth on 30-day-old plants, it was evident that the two varieties were equally susceptible and that antibiosis was not evident in Triveni at that age. Also, population growth in the screenhouse and field studies indicated similar levels of susceptibility in TN1 and Triveni. In spite of supporting similar N. lugens populations, Triveni continued growing and produced grain, whereas in TN1 only a very small amount of grain was produced. This, however, does not preclude the presence of some levels of antibiosis affecting $N$. lugens populations, especially in the older plants. It is not possible to quantify 
the amount that tolerance or antibiosis contributed, but it is apparent that tolerance was of major importance.

Although tolerance has some disadvantages, it would seem desirable to include this component along with antixenosis and antibiosis in breeding for resistance to N. lugens. The presence of tolerance in a rice variety would be expected to decrease the level of damage to the variety, should selection for a virulent biotype occur which could overcome antibiosis. It is expected that tolerance would operate as a horizontal form of resistance to all biotypes. However, before breeding for tolerance to N. lugens can be efficiently conducted, it is necessary to develop efficient methods of evaluating for this component.

\section{Note}

1. Homoptera: Delphacidae

\section{References Cited}

Chen, C. c., W. H. Ko, and R. Chiu. 1978. Rice wilted stunt and its transmission by the brown planthopper, Nilaparvata lugens (Stål). Plant Prot. Bull. Taiwan 20: 376.

Choi, S. Y. 1979. Screening methods and sources of varietal resistance, pp. 171-186. In Brown planthopper: a threat to rice production in Asia. International Rice Research Institute, Los Baños, Philippines. 369 pp.

Headley, J. C. 1972. Defining the economic threshold, pp. 101-118. In N.A.S. Pest Control Strategies for the Future, National Academy of Sciences, Washington, D.C. 389 pp.

Heinrichs, E. A., R. C. Saxena, and S. Chelliah. 1979. Development and implementation of insect pest management systems for rice in tropical Asia. Ext. Bull. No. 127, Food and Fertilizer Technology Center, Taiwan.

Ho, D. T. 1981. Mechanisms of moderate resistance in rice varieties to the brown planthopper, Nilaparvata lugens (Stål). Ph.D. thesis, University of the Philippines at Los Baños, Los Banos, Philippines. 223 pp.

International Rice Research Institute. 1975. Standard evaluation system for rice. Los Baños, Philippines. $64 \mathrm{pp}$.

International Rice Research Institute. 1979. Final report of the International Rice Brown Planthopper Nursery (IRBPHN)-1978. Los Baños, Philippines. 16 pp.

Ling, K. C., E. R. Tiongco, V. M. Aguiero, and P. Q. Cabauatan. 1978. Rice ragged stunt disease in the Philippines. IRRI Res. Pap. Ser. 16. 25 pp.

Paguia, P., M. D. Pathak, and E. A. Heinrichs. 1980. Honeydew excretion measurement techniques for determining differential feeding activity of biotypes of Nilaparvata lugens on rice varieties. J. Econ. Entomol. 73: 35-40.

Painter, R. H. 1951. Insect resistance in crop plants. The MacMillan Co., New York. 520 pp.

Pathak, P. K., and Heinrichs. 1982. Selection of biotype populations 2 and 3 of Nilaparvata lugens by exposure to resistant rice varieties. Environ. Entomol. (in press)

Pathak, M. D., and R. C. Saxena. 1980. Breeding approaches in rice, pp. 421-455. In F. G. Maxwell and P. R. Jennings [eds.], Breeding plants resistant to insects. John Wiley Sons, Inc., New York. $615 \mathrm{pp}$. 
Ho, Heinrichs, and Medrano, EnVironmental Entomology 11 (1982)

Ruben, S., W. Z. Hassid, and M. D. Kamen. 1939. Radioactive carbon in the study of photosynthesis. J. Am. Chem. Soc. 61: 661-663.

Yoshida, Forno, J. Cock, and K. Gomez. 1976. Laboratory manual for physiological studies of rice. The International Rice Research Institute, Los Baños, Philippines. 83 pp. 